\title{
THE ILLINOIS SUPREME COURT AND ZONING: A STUDY IN UNCERTAINTY
}

RICHARD F. BABCOCK*

$\mathrm{M}$

UNICIPAL zoning is the backbone of urban planning and like most vertebrae it suffers from being taken for granted. The promotion of efficient urban housing and transit may be frustrated or ultimately wrecked by a carelessly drawn and indifferently administered zoning map. The availability of private capital or public funds for the eradication of the blight that infects large segments of our urban areas may be jeopardized because a sloppy municipal zoning program threatens the orderly resurrection of our disordered communities.

Unfortunately, however, zoning contains neither the romance of the park and highway program nor the political and social drama of the slum clearance project. Since its early days (when it came dangerously near to becoming a fad) zoning has been-to the city dweller-either a completely forgotten thing or an irritating nuisance suddenly thrust in the path of his plans to develop his property in accordance with his own wishes. ${ }^{x}$ Yet it seems idle to plan seriously the more dramatic aspects of municipal development in the face of a mediocre or bad zoning record. This is especially true with respect to the part the courts will be asked to take in approving future plans for urban rehabilitation. The police powers may be malleable, but once a court has cast a jaundiced eye upon one phase of municipal planning it becomes more difficult to convince the justices of the good faith behind related programs.

I

On the record the Supreme Court of Illinois has not been sympathetic to municipal zoning as it has been practiced in Illinois. During the twentysix years that the state enabling act has been law, ${ }^{2}$ the Court, in eighteen out of twenty-nine cases, has held that a particular zoning ordinance as it was applied to a particular piece of property was unreasonable and, hence,

* Member of the Illinois Bar.

Z Zoning suffers not only from the arrows of irritated laymen but also from the barbs of the more zealous planners. For the thesis that zoning can never be an effective implement in urban rehabilitation because the courts would not sustain zoning laws which were strong enough to accomplish major objectives in planning see Tugwell, The Real Estate Dilemma, 2 Pub. Admin. Rev. $27-40$ (I945).

$=$ Ill. Rev. Stat. (x945) c. $24 \S 73$. 
invalid. ${ }^{3}$ In five of the eleven cases in which the ordinance was sustained the action taken by the city or village (and challenged by property owners) was to reclassify property from a more restricted to a less restricted use. ${ }^{4}$ Since it is generally admitted by critics and administrators alike that one of the greatest evils of Illinois zoning has been the overestimate in the zoning maps of the amount of property needed for commercial purposes, ${ }^{5}$ and since, as a practical matter, the primary function of zoning has been to protect residential property from industrial and commercial encroachments ${ }^{6}$ it is arguable that the record is even more lopsided than the figures suggest. ${ }^{7}$ At least it may be said that any municipality which defends its

3 Ordinance held invalid: 2700 Irving Park Building Corp. v. Chicago, 395 Ill. 138,69 N.E. 2d 827 (1946); Anderman v. Chicago, 379 Ill. 236, 40 N.E. 2d 5 I (I942); LaGrange v. Leitch, 377 IIl. 99, 35 N.E. 2 d 346 (I94); Harmon v. Peoria, 373 Ill. 594, 27 N.E. 2d 525 (I940); Taylor v. Glencoe, 372 Ill. 507, 25 N.E. 2d 62 (I939); Catholic Bishop v. Kingery, $37 \mathrm{I} \mathrm{Ill.}$ 257, 20 N.E. 2d 583 (I939); Johnson v. Villa Park, 370 Ill. 272, I8 N.E. 2d 887 (I938); People ex rel. Kirby v. Rockford, 363 Ill. 3 II, 2 N.E. $2 d 842$ (I934); Reschke v. Winnetka, 363 Ill. 478, 2 N.E. 2 d 7I8 (I936); Ehrlich v. Wilmette, 36I Ill. 213, I97 N.E. 567 (I935); State Bank \& Trust Co. v. Wilmette, 358 Ill. 3 II, r93 N.E. I3I (r934); Merrill v. Wheaton, 356 Ill. 457, I9o N.E. 918 (1934); People ex rel Lind v. Rockford, 354 Ill. 377, I88 N.E. 446 (I933); Tews v. Woolhiser, 352 Ill. 212, I85 N.E. 827 (1933); Forbes v. Hubbard, 348 Ill. I66, I80 N.E. 767 (I932); Kennedy v. Evanston, 348 Ill. 426, I8I N.E. 3 I2 (I932); Michigan-Lake Building Corp. v. Hamilton, 340 Ill. 284, I 72 N.E. 7 IO (I930); People ex rel. Deitenbeck v. Oak Park, 33 I Ill. 406, I63 N.E. 445 (1928). Ordinance held valid: De Bartolo v. Oak Park, 396 Ill. 404, 7 I N.E. 2d 693 (I947); People ex rel. Miller v. Gill, 389 Ill. 394, 59 N.E. 2d 67I (I945); Burkholder v. Sterling, $38 \mathrm{I}$ Ill. 564, 46 N.E. $2 \mathrm{~d} 45$ (I943); Zadworny v. Chicago, 380 Ill. 470,44 N.E. 2d 426 (I942); Avery v. LaGrange, 38I Ill. 432, 45 N.E. 2d 647 (I942); Neef v. Springfield, 380 Ill. 275, 43 N.E. 2d 947 (I942); Morgan v. Chicago, 370 Ill. 347 , I8 N.E. 2d 872 (r938); Evanston Best \& Co. v. Goodman, 369 Ill. 207 , I6 N.E. $2 d$ r 3 I (I938); Rothschild v. Hussey, 364 Ill. 557,5 N.E. $2 d 92$ (x936); Minkus v. Pond, 326 Ill. 467 , I58 N.E. I2I (1927); Western Springs v. Bernhagen, 326 Ill. IOO, I 56 N.E. 753 (I927).

4 People ex rel. Miller v. Gill, 389 III. 394, 59 N.E. 2 d 67 I (I945) (property rezoned from single-family to apartment use); Burkholder v. Sterling, $38 \mathrm{I}$ Ill. 564,46 N.E. $2 \mathrm{~d} 45$ (1945) (from residential to commercial use); Zadworny v. Chicago, 380 Ill. 470,44 N.E. 2d 426 (I942) (from apartment to commercial use); Avery v. LaGrange, $38 \mathrm{r}$ Ill. 432, 45 N.E. $2 \mathrm{~d} 647$ (I942) (from single-family to multiple-family use); Morgan v. Chicago, 370 Ill. 347 , I8 N.E. 2d 872 (I938) (from residential to commercial use).

Zoning ordinances generally divide the community into five or more use districts. The basic divisions (which in many communities are further refined) are: single family residential, two-family or apartment house, commercial, and industrial. Oak Park, Ill., Zoning Ord. (I937) $\$ \S 35.93^{\circ}-35.933$. In some municipalities there are as many as nine use districts. Chicago Mun. Code (Hodes, 1939) $\$$ r $94 \mathrm{~A}-4$.

5 Amortization of Property Uses Not Conforming to Zoning Regulations, 9 Univ. Chi. L. Rev. 477 (I942); Address of Hugh Young, Chief Engineer, Chicago Planning Com'n, before Nat'l Society of Civil Engineers, New York City (Jan. 21, I937); Bartholomew, The Zoning of Illinois Municipalities, I7 Ill. Mun. Rev. 221 (1938).

${ }^{6}$ There has been "a shift of emphasis as to the purpose of zoning, from one of effectuating the planned development of a community to one of attempting to protect property values by preventing harmful intrusions into residential neighborhoods and of seeking to lend an area of special value to areas zoned for commercial and industrial use." Walker, The Planning Function in Urban Governmęnt 23 (I94I).

7 It is not suggested that changed conditions in the municipality or improper zoning in the first place may not justify the reclassification of property to a less restricted use. It does 
zoning ordinance before the Illinois Supreme Court must assume the heavy burden of demonstrating that its regulations differ from the great majority of the zoning ordinances which the Court has scrutinized.

This record of antipathy should be of considerable importance to many people. It must affect the actions of municipal planning authorities who draw up the ordinances. ${ }^{8}$ The decisions of administrative agencies, such as local boards of zoning appeal ${ }^{9}$ and of the municipal councils, ${ }^{\text {,0 }}$ will inevitably be tempered by the knowledge that the highest court in the state has, more frequently than not, frowned upon their efforts. The apparent view of the Court is of some concern to the judges of the Circuit and Superior Courts who bear the initial judicial brunt of the legal attacks upon this phase of urban planning.

Today, this poor record is especially disturbing for two reasons. First, the end of the war has prompted many Illinois communities completely to rewrite their ordinances and reshape their zoning maps. This has been done with great effort and, in many instances, at considerable expense and under the direction of highly skilled professional urban planners. ${ }^{\text {Ix }}$ The resident in his capacity as taxpayer has a considerable investment in the ordinance. The second reason why this problem may cause nervousness, at least among municipal officials and zoning experts, lies in a recent

appear significant, however, that in five of the six cases where the city has sought to lower the use restrictions on a particular piece of land over the protest of neighboring property owners the Supreme Court of Illinois has sustained the municipality while in those cases where the municipality has sought to defend a more restricted classification the Court has, in eighteen out of twenty-three cases, held against the city. Kennedy v. Evanston, 348 Ill. 426 , I8I N.E. 312 (1932), is the only case where the Court held that an amendment lowering the use classification was illegal.

8 Note 65 infra. 9 Note 66 infra.

Io In recent years the more common practice has been to place greater responsibility for the administration of the zoning ordinance in the city council and to restrict the power of the local board of appeals to grant variations to the zoning map. Chicago Mun. Code (Hodes, I939) $\S \mathrm{I} 94 \mathrm{~A}-22$. This shift has been partly due to an uncertainty as to the legal authority of boards of appeal. Cf. Welton v. Hamilton, 344 Ill. 82, r 76 N.E. 333 (I93I). A major reason for placing more authority in the city council has been the belief on the part of planning experts that boards of appeal had been too generous in granting use variations. Thus, it was believed that if a change in the use regulation could be obtained only by an amendment passed by the city council the zoning map would not be subject to so many indiscriminate changes. In theory, at least, an amendment should be for the benefit of the entire community; a variation, however, is granted where a property owner shows "particular hardship." Amortization of Property Uses Not Conforming to Zoning Regulations, 9 Univ. Chi. L. Rev. 477, 495 n. 99 (I942).

Ix Highland Park Zoning Ordinance (Draft, June, I946) prepared by Bartholomew \& Associates, St. Louis, Missouri. The Zoning Commission of Oak Park, Ill., is presently considering a comprehensive urban plan drafted by the same organization. In the past three years Morton Grove and Lincolnwood, Illinois completely revised their municipal zoning ordinances. Chicago revised its zoning map in 1942. In a related field see Preliminary Report of Planning Survey, Clarendon Hills, Illinois, McFudzean, Everly, Rose \& Associates (Jan. 1947). 
amendment to the Illinois Zoning Act. In 1943 the legislature passed an amendment to the Act by the terms of which municipalities may provide for the gradual elimination of uses which do not conform to the regulations of the district in which they are located..$^{22}$ In effect, such an ordinance would mean that a municipality could, after a reasonable period of years, order the owner of a grocery store or a beauty parlor which was located in an area zoned for residential use to cease using the property for anything but residential purposes. ${ }^{13}$ And this without compensation. ${ }^{14}$ This law, and any ordinance enacted thereunder, will face ticklish constitutional questions which unquestionably will eventually be debated before the United States Supreme Court. ${ }^{\text {Is }}$ The attitude of the Illinois Supreme Court as illustrated by the record in zoning cases does not make for sanguine hopes as to the fate of this new provision.

It is suggested then that the history of the judicial attitude toward zoning in Illinois calls for some analysis. In an earlier article the flaws of

Is "The powers conferred by this article shall not be exercised so as to deprive the owners of any existing property of its use or maintenance for the purpose to which it is then lawfully devoted, but provisions may be made for the gradual elimination of uses, buildings and structures which are incompatible with the character of the districts in which they are made or located, including, without being limited thereto, provisions (a) for the elimination of such uses of unimproved lands or lot areas when the existing rights of the persons in possession thereof are terminated or when the uses to which they are devoted are discontinued; (b) for the elimination of uses to which such buildings and structures are devoted, if they are adaptable for permitted uses; and (c) for the elimination of such buildings and structures when they are destroyed or damaged in major part, or when they have reached the age fixed by the corporate authorities of the municipality as the normal useful life of such buildings or structures." Ill. Rev. Stat. (I945) c. $24 \$ 73-$ r. The large majority of Illinois ordinances now provide that existing non-conforming uses may continue except where partially destroyed, or where "discontinued for a certain period of time." Cf. Douglas v. Melrose Park, 389 IIl. 98,58 N.E. 2d 864 (1945). All ordinances restrict additions to non-conforming uses. This provision has been held valid. Mercer Lumber Co. v. Glencoe, 390 IIl. 138, 60 N.E. 2d 913 (I945).

${ }^{13}$ The Chicago ordinance provides that all non-conforming uses shall be discontinued "upon transfer of ownership or termination of the existing lease, as the case may be, of the person in possession as owner or lessee of the property devoted to such non-conforming use on the effective date of this ordinance, unless then maintained in a building designed for such non-conforming use. ...." In such event the ordinance provides for an "amortization" period of from fifty to one hundred years depending upon the type of construction of the building. Chicago Mun. Code (Hodes, I939), $\$$ I94 A-20. Provisions for gradual elimination of the nonconforming use have been incorporated into the zoning ordinances of Lincolnwood and Morton Grove, Illinois. See also Highland Park Proposed Zoning Ord., Bartholomew \& Associates (June, I946), art. XIV.

$I_{4}$ The use of the power of eminent domain for this purpose has never been seriously advocated. Walker, op. cit. supra note 4 at 99 ; cf. State ex rel Twin City Bldg. \& Investment Co. v. Houghton, I44 Minn. I, 174 N.W. 885 (rg19).

t5 For a discussion of the constitutional and practical problems raised by such a provision see Amortization of Property Uses Not Conforming to Zoning Regulations, 9 Univ. Chi. L. Rev. 477, 482-86 (I942); Noel, Retroactive Zoning and Nuisances, 4 I Col. I. Rev. 457 (I94I); Fratcher, Constitutional Law-Zoning Ordinances Prohibiting Repair of Existing Structures, 35. Mich. L. Rev. 642 (1942): Retroactive Zoning Ordinances, 39 Yale L. J. 735, 737 (1930). 
zoning as it has been practiced in Illinois were set out in detail..$^{6}$ There is abundant evidence that zoning has not always been a carefully planned program designed for the benefit of the entire community. The examples of gross overzoning for commercial uses, the indiscriminate granting of use variations and the careless "spot" amendment to the zoning map have been recorded. ${ }^{17}$ It is only a half truth, nevertheless, to say that zoning has been cursed by politics. The boards of appeal who frequently have authority to grant variations in the use to which property is put are generally made up of citizens who are property owners themselves (or real estate agents $)^{\mathrm{x}}$ and they are not eager to be too harsh on their neighbors who may become irked by the zoning restrictions.

Bluntly, the record of Illinois zoning is not one that would inspire any court to place great faith in its preventive, and, much less, its curative powers over the serious ills with which urban land development is afflicted. ${ }^{19}$

\section{II}

Granted, then, that responsibility for the indifferent to bad record cannot be passed off to an arbitrary judicial attitude. Nevertheless, it could be hoped that the Court would take the opportunity to clearly (and, perhaps, with understandable irritation) state what it believed to be the measure of valid municipal zoning. ${ }^{20}$

${ }^{16}$ Amortization of Property Uses Not Conforming to Zoning Regulations, 9 Univ. Chi. L. Rev. 477, 489-96 (I942).

I7 Ibid.

x8 "The disproportionate number of realtors is due primarily to their avowed special interest in zoning and consequent pressure for representation from local realty boards." Walker, op. cit. supra note 6 , at $15 \mathrm{I}$.

x9 In further explanation of zoning's poor record in the courts, the briefs and records presented by attorneys in many of these cases reveal a failure to sustain the burden of proving the value of zoning to the healthy growth of the community. Municipalities have frequently resorted to arguing with complainants over the relative value of land if zoned for commercial rather than residential use, a hopeless debate in which the municipalities have usually come out the loser. See Abstract of Record, Harmon v. Peoria, 373 Ill. 594, 27 N.E. 2d 525 (I940); Abstract of Record, People ex rel. Kirby v. Rockford, 363 Ill. 53x, 2 N.E. 2d 842 (I936). In a few cases cities have called in authorities on municipal planning to assist with the record. Evanston Best \& Co. v. Goodman, 369 Ill. 207, I6 N.E. 2d I3x (I938); Reschke v. Winnetka, $3_{3}{ }_{3}$ Ill. 478,2 N.E. 2 d 7 I8 $(1936)$. The failure to make use of non-legal materials recalls the practice of attorneys vainly defending state minimum wage laws prior to Louis Brandeis' successful use of economic and social statistics in his briefs in Muller v. Oregon, 208 U.S. 4I 2 (Ig08). Mason, Brandeis, A Free Man's Life 252 (I946).

${ }^{20}$ The unsatisfactory record is partly due to some very weak cases which have been permitted to reach the Court. The friction developed by intracommunal quarrels has prompted stubbornness where, to the observer acquainted only with the record and not with the multitude of extra-legal facts and local prejudices, compromise seemed in order. 2700 Irving Park 
What legal standards, if any, has the Supreme Court of Illinois established? If zoning is to mend its ways may it look to the decisions for guidance? Are there certain facts which, reappearing in "sympathetic" decisions and being absent in opinions in which ordinances have been invalidated, give a clue to valid urban planning? Or, if the sequence of facts is ambiguous and confused, has the Court worked out certain principles which may serve as monuments?

Parenthetically, it should be noted that it is difficult to find any clear pattern in the type of zoning case which the Court has passed upon. In eight cases the property owner wanted to erect a gas station in an area zoned residential. ${ }^{2 x}$ In five, a homeowner wished to convert his one-family residence to a two- or multiple-family dwelling..$^{22}$ In three cases the quarrel was over the right to build apartments in areas originally zoned for singlefamily residential use. ${ }^{23}$ Eight cases involved small commercial encroachments into residential areas; ${ }^{24}$ in only one was a sizable manufacturing establishment involved. ${ }^{25} \mathrm{~A}$ school $^{26}$ and a trailer ${ }^{27}$ were in dispute in the remaining cases. The only conclusion at this point is the expected: there has been nothing dramatic in the contest between property owners and

Building Corp. v. Chicago, 395 IIl. I38, 69 N.E. 2d 827 (r946); Catholic Bishop of Chicago v. Kingery, $37 x$ Ill. 257,20 N.E. 2 d 583 (I939). Once removed from their immediate community context these cases become merely precedents which threaten more reasonable efforts to protect the zoning ordinance.

${ }^{2 x}$ Neef v. Springfield, 380 Ill. 275, 43 N.E. 2d 947 (I942); Morgan v. Chicago, 370 Ill. 347 , I8 N.E. 2d 872 (I938); Rothschild v. Hussey, 364 Ill. 557,5 N.E. 2 d 92 (1936); State Bank \& Trust Co. v. Wilmette; 358 Ill. 3 II, I93 N.E. I3I (I934); People ex rel. Lind v. Rockford, 354 Ill. 377 , I88 N.E. 446 (1933); Tews v. Woolhiser, 352 Ill. 212, I85 N.E. 827 (1933); People ex rel. Deitenbeck v. Oak Park, $33 x$ Ill. 406, I63 N.E. 445 (x928); Western Springs v. Bernhagen, 326 Ill. Ioo, $5_{5} 6$ N.E. 753 (1927).

22 DeBartolo v. Oak Park, 396 Ill. 404, 7I N.E. 2d 693 (x947); Avery v. LaGrange, 38 I Ill. 432, 45 N.E. 2 d 647 (I942); Anderman v. Chicago, 379 Ill. 236, 4 O N.E. 2d 5 I (I942); Harmon v. Peoria, 373 Ill. 594,27 N.E. 2 d 525 (I940); Merrill v. Wheaton, 356 Ill. 457 , I9o N.E. 9 I 8 (1934).

${ }^{23}$ People ex rel. Miller v. Gill, 389 Ill. 394, 59 N.E. 2d 67 I (I945); Kennedy v. Evanston, 348 Ill. 426, I8I N.E. 322 (1932); Minkus v. Pond, 326 Ill. 467, I58 N.E. I2I (1927).

${ }_{24}$ Burkholder v. Sterling, 38I Ill. 564,46 N.E. 2d 45 (I943) (type of commercial use not specified); Zadworny v. Chicago, 380 Ill. 470,44 N.E. 2d 426 (1942) (motion picture theatre); Taylor v. Glencoe, 372 Ill. 507, 25 N.E. 2d 62 (I939) (unspecified commercial use); Johnson v. Villa Park, 370 Ill. 272, 18 N.E. 2d 887 (I938) (undertaking parlor); Evanston Best \& Co. v. Goodman, 369 Ill. 207 , I6 N.E. 2d I3I (I938) (retail dry goods store); Reschke v. Winnetka, 363 Ill. 478 , 2 N.E. 2 d $7 \times 8$ (I936) (storage of building materials); Ehrlich v. Wilmette, $36 \mathrm{I} \mathrm{III.}$ 213, $x_{97}$ N.E. 567 (r935) (unspecified); Forbes v. Hubbard, 348 Ill. I66, I80 N.E. 767 (I932) (two-story brick building).

${ }_{25} 2700$ Irving Park Building Corp. v. Chicago, 395 Ill. 138,69 N.E. 2 d 827 (1946).

${ }^{26}$ Catholic Bishop v. Kingery, 37x Ill. 257, 20 N.E. 2d 583 (x939).

${ }_{27}^{27}$ LaGrange v. Leitch, 377 Ill. 99, 35 N.E. 2d 346 (r94r). 
municipalities since the early days when zoning's constitutionality was being challenged. ${ }^{28}$ The private interests have been those of the "average citizen" who is annoyed over what he believes to be a silly restriction upon his inalienable rights. No industrial goliath has moved into the legal arena to challenge zoning. This has, of course, made the battle a little more difficult for zoning's proponents.

If the source of the cases turns up little in the way of a clue, the search for a pattern of facts is equally discouraging. A few examples of fact situations common to nearly all zoning cases will illustrate the uncertainty.

The ordinance caused a considerable loss in the value of the property in question.

The most consistent weapon that has been employed in suits challenging the validity of zoning ordinances has been the contention that by zoning land for residential use it affects a loss of property value to the owner who envisions his land as the site of a commercial enterprise. This charge has been used with considerable effect in a number of cases. In People ex rel. Lind v. City of Rockford, ${ }^{29}$ a permit to build a gas station was denied by the city because the property was zoned for residential purposes. In ruling that the ordinance as applied to this property had no relation to the "public health, safety, welfare, and morals" and thus was unconstitutional, the Court said:

There is ample evidence in the record to justify a finding that the lots involved in this litigation are worth as little as $\$ 600$ each for residence purposes .... while on the other hand, the evidence would justify a finding that for business purposes the lots would be worth as much as $\$ 8,000$ each. ${ }^{30}$

In State Bank and Trust Co. v. Wilmette ${ }^{3 \mathrm{x}}$ the Court, in holding an ordinance invalid in conformity with the protest of a property owner who wished to erect a gas station in a residential area, observed that "to enforce the zoning ordinance would depreciate the property in question from $\$ 200$ per front foot to $\$ 50 . " 3^{2}$ Indeed, in almost every case in which an ordinance has been held invalid the Court has stressed the loss in property value. ${ }^{33}$

${ }^{28}$ The United States Supreme Court upheld zoning against attack on constitutional grounds in Euclid v. Amber Realty Co., 272 U.S. 365 (1926).

${ }^{29} 354$ Ill. 377 , 188 N.E. 446 (I933). (1934).

${ }^{30} \mathrm{Ibid}$., at 379 and 447 . Cf. People ex rel. Kirby v. Rockford, 363 Ill. 3 II, 2 N.E. $2 d 842$

${ }^{32} 358$ Ill. 3 Ir, I93 N.E. I3I (I934). 32 Ibid., at 325 and 136 .

33 See, for example, Taylor v. Glencoe, 372 Ill. 507, 512, 25 N.E. 2d 62, 65 (1939) (three times more valuable for commercial than residential use); Reschke v. Winnetka, 363 Ill. 478 , 2 N.E. $2 d 7 \times 8$ (1936) (worth $\$ 30$ for residential, \$125 for commercial use). 
Since it is apparent that "expert" estimates as to decline in "value"-are possible in almost every case where the use of property is restricted, the above cases suggest that the position of the municipality is hopeless. As a matter of fact, the situation, while not hopeless, is confused. In Evanston Best $\mathcal{E}^{\circ}$ Co., Inc. v. Goodman ${ }^{34}$ petitioner asked the city of Evanston for a permit to construct a retail store in an area zoned for apartment use. The property was located on the edge of the principal business district and on a heavily traveled thoroughfare. The Court sustained the action of the city and held the ordinance as applied to petitioner's property to be a valid exercise of the police power. The Court said:

Petitioner emphasizes the fact that its property would be far more valuable if zoned for commercial purposes, but this fact exists in every case where the intensity with which property may be used is restricted by zoning laws. 35

In the more recent case of Neef $v$. Springfield ${ }^{36}$ the Court accepted evidence that certain property was worth $\$ 3,500$ for commercial use and only $\$ \mathbf{1 , 2 0 0}$ for residential purposes. The ordinance, however, was held valid. In so far as the "loss-in-value" argument was concerned the Court stated what would appear to be applicable in many cases:

... . to permit appellants' lots to gain in value it is necessary for the entire neighborhood to lose and the city to suffer by the resulting loss in taxable value. The prevention of such a loss by the city is one of the specific purposes for which the zoning power is granted, and it is directly related to the public welfare. On this ground alone we think the ordinance should be sustained. 37

The property in dispute is near land which is devoted to non-conforming uses or is on the periphery of the more restricted use district.

One of the most troublesome problems which faces the planners and administrators of zoning ordinances is where to draw the boundary lines of use districts. The haphazard growth of our cities and villages has resulted in an interlarding of strips of residential areas with stores, gas stations, and even heavy industrial properties. To superimpose a use map upon an established urban area must inevitably result in creating large numbers of non-conforming uses and, in many cases, in establishing dividing lines between use districts which will offend those who own property on or near the border line. In many of the cases property owners who contest the ordinance underscore the apparent disparity between their restricted rights and the freedom of their neighbors who either operate a non-conforming use or are in a neighboring area zoned for a less restricted use.

${ }^{34} 369$ Ill. 207 , I6 N.E. 2 d I3I (I938).

35 Ibid., at 2 II and 133 .
${ }^{36} 380$ Ill. 275,43 N.E. $2 d 947$ (1942).

32 Ibid., at $280-8 \mathrm{I}$ and 950 . 
The resolution of this problem would seem to rest primarily with the municipal planners and administrators. This was the opinion of the Court in the Neef case. There the owner of property located on a through boulevard wanted to erect a gas station. The area was zoned exclusively for residential purposes. The evidence tended to establish that the land in the immediate area was devoted to mixed residential and commercial uses. Private homes appeared in close proximity to a souvenir shop, a grocery store, and a lunch stand. The local board of appeals recommended to the city council that the property be rezoned to permit the construction of a gas station. This the council refused to do. The petitioner then sought to enjoin the city from enforcing the ordinance. Although the master in chancery recommended that the writ issue, the chancellor dismissed the bill. In sustaining the decision of the lower court the Court laid down the following rule:

Appellants' contention that it is unreasonable to allow their neighbors' property a commercial classification, and deny the same classification of their property cannot be sustained. This argument would lead to the conclusion that the next adjoining lot in the north would then, by the same logic, become entitled to commercial classification, and so on until the entire neighborhood was reclassified and commercialized. . . . The problem of whether . . . [ [appellants' lot] is to be characterized by the residential area adjoining it on the north and facing it on the west and south or by the commercial area adjoining it on the east is certainly debatable and one to be answered by the city conncil and not by this court so long as the city acts within its powers. ${ }^{8}$

This was not a new doctrine. In I932 the Court had recognized that "the very nature of the zoning ordinance requires that certain desirable neighborhoods adjoin others less desirable." 39 In I935, however, a property owner sought an injunction against the enforcement of the zoning ordinance by the village of Wilmette. ${ }^{40}$ His property which was zoned residential was on the edge of a small neighborhood shopping district. A suburban electric railway terminus was nearby. Apartments and one-family residences adjoined his property on two sides. Beyond the small shopping district the area was almost exclusively devoted to residential use. This time the master reported in favor of the village but the chancellor issued the injunction. The Court sustained the chancellor with these words:

Here appellee's property is not characterized by the residence area lying west and south, but rather by the business district to the north and the commercial and industrial property across the street and by the use of the street as a business street.42

${ }^{38} \mathrm{Ibid}$, at $282-83$ and 95 I (italics added).

39 Kennedy v. Evanston, 348 Ill. 426, 433, I8I N.E. 312, 314 (r932).

40 Ehrlich v. Wilmette, 36 I Ill. 2I3, I97 N.E. 567 (1935). $\quad 4$ Ibid., at 225 and 572. 
In an earlier case the Court had invalidated a zoning ordinance with this comment:

There being another gasoline filling station and other service stations and garages located and in operation within the same area as appellant's property, little could be said in support of the ordinance as being for the benefit of the public health, morals, safety or welfare..$^{42}$

One should not assume that the Neef case has upset the yiews expressed in these earlier cases. Remarks similar to those quoted are still to be found in the later cases. ${ }^{43}$

The ozener purchased the property after the ordinance was in existence and thus had at least constructive notice of the restriction upon the use of his land.

It has been the belief of some municipal officials that successful attacks upon zoning ordinances would diminish as property changed hands and an increasing number of grantees took title to property after it had been zoned. It was hoped that by application of a rule of constructive notice the purchasers of land the use of which was restricted would be estopped from challenging the validity of the ordinance. That there was some legal foundation for this theory was suggested by the Court in the Evanston Best $\&^{\circ}$ Co. case:

Petitioner was well aware of the restriction upon the use of the property in this district when it purchased the lot in question and the evidence it has produced in this case raises questions which, at most, are debatable. 44

In 1936 the Court observed in Rothschild v. Hussey, ${ }^{45}$ that the petitioner had purchased the property after the ordinance was passed:

At the time this suit was begun [the ordinance] .... had been in force for nearly ten years and real estate was purchased and many improvements made in reliance upon its restricted classifications..$^{6}$

Nine years earlier the Court had dismissed a bill for injunctive relief against a city, stating: ·

Appellant bought his property after the zoning commission had been appointed and after most of the territory had been surveyed. 47

42 People ex rel. Deitenbeck v. Oak Park, 33I Ill. 406, 4I2, I63 N.E. 445, 447-48 (x928).

' 43 "In ascertaining whether the application of the zoning ordinance to plaintiffs' property transcends constitutional guarantees the character of the property in the immediate neighborhood, in contradistinction to the character of [the distríct] as a whole, requires consideration." Harmon v. Peoria, 373 Ill. 594, 6or, 27 N.E. 2d 525, 528 (1940).

${ }_{44} 369$ IIll. 207, 21I-r2, $x 6$ N.E. 2 d I3x, $\mathrm{r}_{33}$ (1938).

${ }_{45} 364$ Ill. 557,5 N.E. $2 d 9_{2}$ (1936).

${ }_{4}^{6} \mathrm{Ibid} .$, at 560 and 93 .

${ }_{47}$ Western Springs v. Bernhagen, 326 Ill. 100, I03, I56 N.E. 753, 754 (1927). 
Yet in I932 the Court, in Forbes v. Hubbard, ${ }^{48}$ in reply to the defense that the property had been purchased after the ordinance had been passed, stated flatly:

We know of no rule of law that creates an estoppel against attack by such purchaser on the validity of a zoning ordinance.49

In I940 this statement was cited with approval in Harmon v. City of Peoria.so

Closely related to the above problems is the question, in cases where a property owner seeks to have his property reclassified from residential to commercial, whether it is a significant fact that there already is in the urban area large tracts of land available for commercial development. Again, the answer apparently is sometimes yes and sometimes no. ${ }^{.5}$

\section{III}

If the Court has failed to indicate clearly what facts are significant in determining the validity or invalidity of a zoning regulation, the statements of principle which appear in the cases are no more edifying. ${ }^{52}$ One can find only general propositions satisfactory to city or property owner, depending upon which cases are cited. Thus, in those cases where the Court has sustained the ordinance, one invariably finds a statement closely approximating the following:

The power of a city or village to adopt comprehensive zoning laws is based upon the police power, and their prohibitive restrictions are valid if they bear a reasonable relation to the public comfort, morals, safety and general welfare..... We have repeatedly held that these relative factors are determinative regardless that here and there some individwal may suffer an invasion of his property. 53

${ }^{8} 348$ IIl. 166,180 N.E. 767 (1932).

49 Thid., at 175 and 77 I.

so 373 Ill. 594, 602, 27 N.E. 2d 525, 529 (1940).

st Compare Forbes v. Hubbard, 348 Ill. $166,18 \mathrm{I}-82,180$ N.E. 767,773 (1932) with Kennedy v. Evanston, 348 Ill. 426 , 433, I8I N.E. 3 I2, 314 (1932).

${ }_{52}$ There is one point on which there appears to be no room for debate: the Illinois Supreme Court does not believe that an ordinance which excludes two-family dwellings from residential areas in which boarding houses, golf courses, schools and farms are permitted is a reasonable exercise of the police power. Anderman v. Chicago, 379 IIl. 236, 40 N.E. 2d 5I (1942); Harmon v. Peoria, 373 Ill. 594, 27 N.E. 2d 525 (1940); Merrill v. Wheaton, $35^{6}$ Ill. 457, rgo N.E. 918 (I934). But cf. DeBartolo v. Oak Park, 396 Ill. 404, 7 N N.E. 2d 693 (1947).

Since many Tllinois zoning ordinances permit such uses in areas where two-family residences are forbidden, the serious problem of protecting single-family areas from invasion by two-family dwellings will not be easily solved.

${ }_{33}$ Rothschild v. Hussey, 364 Ill. 557, 559, 5 N.E. 2d 92, 93 (1936) (italics added). 
In the more frequent cases where the ordinance has been invalidated the following frequently repeated rule neutralizes if it does not impliedly contradict the above:

If a restrictive ordinance bears no real and substantial relation to the preservation of the public health, safety or welfare, but is, in fact, a capricious invasion of property rights, then such an ordinance becomes invalid and cannot be sustained.54

The most serious issue, however, on which it would be hoped that a clear rule would be established is the scope of the Court's review of each zoning case and the extent to which each ordinance will be given the benefit of any doubt. The following statement made in Morgan v. Chicagoss would appear to represent a sound willingness to give considerable freedom to the discretion of the administrative or legislative body responsible for the ordinance:

It is primarily the province of the municipal body to which the zoning function is committed, to draw the line of demarcation as to the use and purpose to which property shall be assigned or placed, and it is neither the province nor the duty of courts to interfere with the discretion with which such bodies are vested, in the absence of a clear showing of an abuse of that discretion..... Whether the action of the city council in passing the variation ordinance was an unreasonable, arbitrary or unequal exercise of power may be fairly debatable. Yet in such instances we have established the rule that this court will not substitute its judgment for that of the legislative body charged with the primary duty and responsibility of determining the question. . . ..$^{56}$

Has the Court established such a rule? In Reschke v. Village of Winnetk,$^{57}$ the Court held an ordinance invalid because it prevented the use of a lot for commercial purposes. Zoning experts Harland Bartholomew and Jacob L. Crane testified for the village. On the other side, real estate experts said that the property was worth $\$$ I25 a foot for commercial purposes but only $\$ 30$ a foot for residential use. Though located on a through highway and close to some small business enterprises, the tract also adjoined residential property. Before reaching its decision the Court reiterated that "if the restrictions [imposed by the ordinance] are considered either doubtful or fairly debatable, courts should not substitute their judgment for that of the legislative body of the particular municipality." 58

54 Taylor v. Glencoe, 372 Ill. 507, 510-II, 25 N.E. 2d 62, 65 (1939) (italics added).

55370 Ill. 347 , I8 N.E. $2 \mathrm{~d} 872$ (1938).

${ }^{6} \mathrm{Tbid}$, at 350 and 873 . "It must be emphasized at the outset that this court is not a zoning commission. All questions concerning the wisdom or desirability of particular restrictions in a zoning ordinance must be addressed to the legislative bodies specifically created to determine them." Evanston Best \& Co. v. Goodman, 369 Ill. 207, 209, I6 N.E. 2d I3I, I32 (I938).

${ }^{57} 363$ Ill. 478,2 N.E. 2 d 7 I8 (I936).

$5^{8} \mathrm{Ibid}$., at 485 and $72 \mathrm{I}$. 
The reasonableness of this ordinance would seem to have been, at the very least, debatable. The local zoning board of appeals and the city council had refused to change the ordinance; in this opinion they had been sustained by the master and the lower court. The Court, nevertheless, concluded that the ordinance was unreasonable beyond all debate and thus invalid.

In I934 the Court held invalid an ordinance of Wheaton, Illinois, which restrained a property owner from remodeling his single-family residence into a two-family dwelling. ${ }^{59}$ In this case the administrative agency, the city council, and the chancellor had found the ordinance a reasonable exercise of the police power.

When, in I940, the Court again held that the unreasonableness of a zoning ordinance was not debatable, although the city council, the master in chancery and the chancellor had thought it reasonable, ${ }^{60}$ Justice Wilson, dissenting, was constrained to observe:

Although this court has recently proclaimed that it is not a zoning commission and that all questions with respect to the wisdom or desirability of particular zoning restrictions must be addressed to the legislative bodies specifically created to determine them .... it is manifest that the decision in the case at bar is a departure from this sound and salutary rule. ${ }^{6 x}$

Justice Wilson could, indeed, have quoted the words of the Court in Morgan v. City of Chicago:

.... a decision of this case depends primarily on the facts, and these have been passed upon by five different agencies created for that purpose: First by the board of appeals; second, by the subcommittee of the city council; third, by the city council itself; fourth, by the master in chancery; and fifth, by the chancellor. ${ }^{62}$

The only possible conclusion is that, although the Court early spelled out the orthodox rule of statutory construction that "the presumption is in favor of the validity of a zoning or other ordinance adopted pursuant to a legislative grant," ${ }_{3}$ the result of the cases appears to require the municipality to show "affirmatively and clearly" its reasonableness.

The legal status of zoning in Illinois is in complete confusion and this despite the fact that its constitutionality was recognized twenty-two years ago. No professional city planner can confidently advise a municipality whether any portion of the zoning map will stand up under legal attack.

\footnotetext{
59 Merrill v. Wheaton, 356 Ill. 457, 190 N.E. 9I8 (1934).

60 Taylor v. Glencoe, 372 Ill. 507, 25 N.E. 2d 62 (I939).

62 Ibid., at $5 \times 3$ and 67 .

${ }^{62} 370$ Ill. 347, 350-51, x8 N.E. $2 d 872,873$ (I938).

${ }_{63}$ Rothschild v. Hussey, 364 Ill. $557,559,5$ N.E. 2 d 92, 93 (1936).
} 
No city attorney can prepare his case with the confidence that the facts are favorable or that the rules set down by the Court in earlier cases point in a favorable direction. Equally important, in many instances it is diffcult for an attorney or city planner to counsel the municipality that a particular issue is better compromised than contested.

It should be again emphasized that the blame for this confusion should not be placed on the Court. The inconsistency and lack of sympathy displayed by the cases is attributable in great part to the complete inadequacy of zoning as it has, by and large, been practiced in this state. There is some evidence, however, that progress is being made in the direction of improving the administration of this phase of urban planning. ${ }^{64}$

\section{IV}

At this time it may thus be worthwhile to suggest a few standards which might be used to measure the validity of zoning ordinances in order that the hoped-for improvement in zoning practice may be met by a fresh judicial approach.

Far greater significance should be given to the procedural due process which the complaining property owner has obtained. This should be of particular importance in those cases where the ordinance has been sustained by agencies further down the judicial ladder. If it can be clearly demonstrated I) that the original zoning map was established only after adequate hearings ${ }^{65}$ and 2 ) that the complainant has been given a complete

${ }_{64}$ In I940 Evanston, Illinois restored large areas to residential use. In $x 942$ Chicago revised its zoning map adding large areas to residential use and cutting down some of the property zoned but not used for commercial use. See also note II supra. It is too early, however, to state that there has been any permanent improvement in the day-to-day administration of zoning ordinances.

${ }_{65}$ Section 2 of the state enabling act provides for the creation of a zoning commission by the "corporate authorities in each municipality which desires to exercise the powers conferred by this article...." After the preparation of a tentative report and a proposed zoning ordinance the commission is required to hold a hearing and "shall afford persons interested an opportunity to be heard." Notice of the hearing must be given by publication at least fifteen days in advance of the meeting "in a newspaper of general circulation in the municipality." The notice must state the time and place of the meeting and the place where copies of the proposed ordinance will be available for inspection. The commission must report to the "corporate authorities" and submit to them a copy of the proposed ordinance within thirty days following the hearings. The authorities may enact the ordinance "with or without change or may refer it back to the commission for further consideration."

Under this section one series of public hearings is mandatory and two are possible before the ordinance is enacted. Ill. Rev. Stat. (1945) c. $24 \$ 73^{-2}$. On one or two occasions the court has taken notice of the importance of these preliminary hearings. State Bank and Trust Co. v. Wilmette, 358 Ill. 3II, 3I8, I93 N.E. I3I, I33 (I934); Western Springs v. Bernhagen, 326 IIl. 100, 103, I56 N.E. 753, 754 (1927).

By providing that the zoning commission "shall cease to exist upon the adoption of the zoning ordinance" Section 2 may anticipate practical necessities in smaller communities but it also mirrors the general initial enthusiasm followed by public and official indifference which frequently is the history of zoning ordinances. 
hearing on his request for an amendment or a variation to the zoning map before the city council or the board of appeals, then the municipality's case should be recognized as strong. ${ }^{66}$ It is extremely difficult for a court of last resort to do an adequate job of analyzing the substantive merits of a city-wide zoning ordinance as it applies to one piece of land. A good ordinance can only be drawn with a view to the future needs as well as the present condition of the municipality ${ }^{67}$ a good ordinance must consider each piece of property as an integral part of the entire community, not as an isolated bit of land. Yet when a case comes before the Supreme Court it is almost impossible to view the issues in this perspective. What the Court sees is a small plot of land, independent of the rest of the urban area and unrelated to any future development. Only the Court, however, can fairly determine whether the objector has received a fair airing of his complaint. If the municipality can establish this-and in not a few instances there has been serious doubt that a fair or adequate hearing has been given ${ }^{68}$ - then the circumstances should be extreme to justify a reversal of the opinion of the legislative or administrative body. ${ }^{69}$

The phrase "extreme circumstances" suggests the second factor which should be considered by the Court: the presence of political or neighborhood pressures which have distorted the purpose of the ordinance. There are examples in the cases. The refusal to permit a parochial school to be built in an area where public schools are permitted, ${ }^{70}$ and the granting of an amendment for the purpose of allowing a sixty-story building to be

${ }^{66}$ Under Section 3 of the Act the city council or board of trustees may provide for the appointment of a board of appeals consisting of five members serving staggered terms of five years each. The board is charged with hearing appeals from any administrative officer responsible for enforcing the ordinance. The concurring vote of four members of the board is required to reverse the order of such administrative officer or to decide "in favor of the applicant any matter upon which it is required to pass under such an ordinance or to effect any variation in the ordinance, or to recommend any variation or modification in the ordinance of the corporate authorities." Under Section 4 of the Act the ordinance may provide that either the board of appeals or the city council may grant variances to the regulations. No variation may be granted except after a public hearing before the board of appeals of which there must be a fifteen-day published notice. Every change whether in the form of a variation by the board of appeals or by ordinance after a hearing before the board must be accompanied by " $a$ finding of fact specifying the reason for making the variation."

Section 5 of the act establishes the procedure for an appeal by a complainant from the order of an administrative officer to the board.

${ }^{67}$ See Mercer Lumber Co. v. Glencoe, $39 \circ$ Ill. I38, 145, 60 N.E. 2d 9ז3, 9 I7 (I945).

${ }^{68}$ See report on field study of records of hearings before zoning boards of appeals in a number of Illinois municipalities, Amortization of Property Uses Not Conforming to Zoning Regulations, 9 Univ. Chi. L. Rev. 477, 492-94 (1942).

69 The Supreme Court does not consider the board of appeals to be more than a "minor administrative body" whose report is "entitled to no more weight than the conclusions of a witness resting upon facts not in evidence." Behnke v. President and Bd. of Trustees of Brookfield, 366 IIl. 516, 519, 9 N.E. 2d 232, 233 (1937).

${ }^{70}$ Catholic Bishop v. Kingery, $37 x$ IIl. 257, 20 N.E. 2d 583 (1939). 
erected in an area limited to thirty-story structures and the repeal of this amendment immediately after the permit had been granted ${ }^{7 x}$ are examples. The Court, however, has stated in a recent zoning case that the motives behind legislative action will not be inquired into. ${ }^{72}$ In other words, political or neighborhood pressures behind action of a city council would not influence the decision as to the merits of a particular ordinance. But evidence of this in the record would appear to be a fair basis for attack upon the ordinance. ${ }^{73}$ Indeed, the Court has taken oblique notice of politicking with a zoning ordinance in the recent case of 2700 Irving Park Building Corporation v. City of Chicago. ${ }^{74}$ In 1942 the city of Chicago rezoned certain properties from industrial to apartment use. The Court made the following comments on the motives behind the amendment:

The witness Ross [a former alderman] testified that his purpose in promoting the I942 amendment, rezoning the west 125 feet of the 53 -acre tract to apartment use, was a temporary restriction of the use of the whole tract with the idea that eventually the "entire tract would be used for park purposes or, in his own words, "to build a wall around there knowing that they could not build on the inside and it would be too damned expensive and I wanted a park there." Witness Gurman, who succeeded Ross, as alderman, expressed the same purpose; the extent to which he was willing to go in keeping factories out of the tract is indicated by the fact that he commenced a suit late in 1942 to temporarily prevent the plaintiff, among others, from making an industrial or manufacturing use of the property. This suit was discontinued as soon as the I943 amendment was passed.

The Court then drew the fine line between motives of the city council and motives of those who "promoted" the amendments:

As already observed it would be improper for this court to consider the motives of the city council in enacting the ordinances of 1942 and $x 943$. It is, however, pertinent to observe that those promoting those amendments were motivated by a desire to prevent the use of the property for manufacturing purposes until such time as their dream of a playground or a park could become a reality. Those interested in this movement included one of the city's expert witnesses, Dobroth. These parties were not con-

7 Michigan-Lake Building Corp. v. Hamilton, 340 Ill. 284, I72 N.E. 7 I0 (I930).

72 "The courts cannot inquire into the factors or reasons which motivated the council in passing the ordinances." 2700 Irving Park Building Corp. v. Chicago, 395 Ill. 138, 147, 69 N.E. $2 \mathrm{~d} 827,83 \mathrm{r}\left(\mathrm{r}_{946)}\right.$.

73 Evidence of political or neighborhood pressures would tend to indicate that the action taken did not conform to the stated purposes of the Act:

"To the end that adequate light, pure air, and safety from fire and other dangers may be secured, that the taxable value of land and buildings throughout the municipality may be conserved, that congestion in the public streets may be lessened or avoided, and that the public health, safety, comfort, morals and welfare may otherwise be promoted, the corporate authorities in each municipality have the following powers....." III. Rev. Stat. (x945) c. 24 $\S 73^{-I}$.

${ }^{74} 395$ Ill. 138,69 N.E. $2 d 827$ (1946). 
cerned with having the 53-acre tract devoted to its highest and best private use; rather their desire was to keep it from being used at all until such time as it could be converted into a playground or a park. These facts are proper to be considered in weighing the testimony. 75

The need for greater emphasis upon the procedural aspects and upon the absence of political or neighborhood pressures is suggested not merely by an appreciation of the proper function of the courts in zoning. If the Court were to stress these factors one might expect some improvement in the dayto-day administration of the ordinance. Candid judicial criticism of improper or careless administration might make it apparent that it is an extravagant waste of taxpayer's money to draw up a careful urban plan and then permit it to degenerate by careless administration. The decisions of the Court with their emphasis upon land values and non-conforming uses tend to divert attention away from the serious flaws in zoning: indifferent or incompetent administration of what may originally have been a carefully planned ordinance.

Thirdly, it is suggested that the Court should lead the way in discounting the exaggerated emphasis which has been placed upon the relative value of a piece of land for commercial or residential uses. The Illinois statute does require that zoning ordinances give consideration to existing land values..$^{76}$ This should mean, however, land values throughout the entire urban area. As the Court has observed, to permit the use of one piece of land for commercial purposes may well mean the loss in value of other land in the neighborhood and, eventually, in the entire community. ${ }^{77}$ Furthermore, it seems apparent that any restriction upon the use of most land is going to affect its marketability and thus tend to diminish its value. This result is inherent in zoning. Twenty years ago the Supreme Court of the United States held that such a loss was no constitutional objection to zoning. ${ }^{8}$ That opinion, together with the decision of the Illinois Supreme Court in Aurora v. Burns ${ }^{79}$ should have removed the question

75 Ibid., at $150-5 \mathrm{I}$ and 833 .

${ }^{66}$ "In all ordinances passed under the authority of this article, due allowances shall be made for existing conditions, the conservation of property values, the direction of building development to the best advantage of the entire municipality and the uses to which the property is devoted at the time of the enactment of such an ordinance." Ill. Rev. Stat. (I945), c. 24 $\S 73^{-1}$.

77 Neef v. Springfield, 380 Ill. 275, 280, 43 N.E. 2d 947, 950 (I942). But see Taylor v. Glencoe, 372 Ill. $507,512,25$ N.E. 2d 62, 65 (I939).

${ }^{8}$ In the famous Euclid case the record showed that the realty company's land was worth about $\$ r 0,000$ an acre for industrial purposes while its value when zoned for residential use was about $\$ 2,500$. Euclid v. Ambler Realty Co., 272 U.S. 365, 384-85 (1926).

${ }^{79} 3$ I9 Ill. 84 , I49 N.E. 784 (x925). 
of value from practically all zoning cases. In all but the most extreme cases where restrictions have demonstrably made property useless, the decision as to the relative "losses" all property owners must assume for the good of the community should rest with the legislative body responsible for the enactment of the ordinance.

Finally, less emphasis should be placed upon the fact that the property which is the object of the controversy is near non-conforming uses or is on the edge of a particular use district. A property owner may feel aggrieved if his property is restricted to residential use while in the same, or in an adjacent block there is a beauty parlor, a corner grocery or a gas station. Similarly, his protest may have a reasonable color should his undeveloped property be a block away from a commercial district. But the record of cases indicates that usually it is the hard cases which reach the courts and it is in these cases where expert judgment and local experience are essential that the Court should honor the decision of the legislative bodies.

It thus seems necessary that less emphasis be placed upon "value" and upon existing non-conforming uses or district lines and that increasingly candid attention should be given to the actual administration of the ordinance in the case before the Court. If the Court is skeptical of zoning because it has been subject to the pressures of politics and property owners or real estate associations, then it is time to criticize zoning on that basis rather than to stress factors which will inevitably exist even under the most ideally administered zoning ordinance. Evidence of an intelligently and carefully drawn zoning ordinance, the impartial and active administration of the ordinance, and proof of the relation of the particular part of the ordinance in question to community needs, not only today but twenty-five years from today, should be the primary considerations in determining whether an ordinance is a reasonable exercise of the police power.

In view of the spotty record of zoning administration the Court cannot be expected to initiate such a change in emphasis. A new approach myst be taken by the communities. This means that attorneys defending the ordinance must be prepared to demonstrate that the complainant has been given a fair hearing by the administrative and legislative bodies. It should be a part of each defense to demonstrate that the ordinance has not become a pork-barrel subject to frequent amendment or variation for favorably situated property owners. So fortified, the defenders of the ordinance should be prepared to break down the reliance of aggrieved property owners upon the "value" test, and should move the contest into an arena where they may demonstrate the merit of zoning-as it is being 
practiced in their community-as a means of protecting land values throughout the city. Finally, the municipality must be prepared to interpret "the protection of land values" in terms of proper density of population, the prevention of blighted areas, the elimination of traffic congestion and the encouragement of both residential and business growth. ${ }^{80}$

The legal status of zoning in Illinois will remain an uncertain and troublesome thing until the administrators are able to give city attorneys a good record and those attorneys are willing to use that record as a means of demonstrating the important function of zoning in urban land development to the Court. It may be expected that when such a record is presented to the Supreme Court of Illinois, the good faith of the community will be rewarded by a sympathetic clarification of the legal rules by which zoning is to be measured.

80 There is a growing awareness that too frequently planning commissions in viewing zoning exclusively as a method of protecting residential values have actually retarded proper residential development. Thus until recently most ordinances permitted residential buildings in areas zoned for commercial or industrial use, a practice which permitted indiscriminate residential growth and consequent deterioration of many residential buildings. In this respect, at least, the Chicago ordinance is illustrative of the more recent approach. Chicago Mun. Code (Hodes, r939) § I94A-9. 